\title{
Peningkatan Praktik Mandiri Ibu dalam Pemantauan Status Gizi Balita melalui Pendampingan Aktivitis Dasa Wisma
}

\author{
Enhancing the Independent Practice of Mothers in Monitoring the \\ Nutritional Status of Toddlers through Dasa Wisma Assistance
}

\author{
Nugraheni, S.A ${ }^{1}$, Aruben, R ${ }^{1}$, Prihatini, I.J ${ }^{2}$, Sari' ${ }^{1}$, Sulistyawati, E ${ }^{1}$ \\ ${ }^{1}$ Fakultas Kesehatan Masyarakat, Universitas Diponegoro \\ ${ }^{2}$ Fakultas Ilmu Kesehatan, Universitas Pesantren Tinggi Darul Ulum \\ (nugraheni.sa.undip@gmail.com)
}

\begin{abstract}
ABSTRAK
Kejadian malnutrisi di Indonesia, juga di Jawa Tengah dan Kota Semarang sampai saat ini masih tinggi, juga masih kurangnya kesadaran dan pengetahuan masyarakat termasuk ibu tentang pemantauan status gizi, serta belum pernah terbentuk kelompok anggota masyarakat yang peduli tentang gizi. Tujuan dari penelitian ini adalah menganalisis perubahan sikap dan praktik dari ibu terkait gizi balita setelah pendampingan aktivis dawis. Penelitian dilakukan di wilayah kerja Puskesmas Tlogosari Wetan Kota Semarang dengan alasan wilayah Puskesmas tersebut memiliki sejumlah Dasa Wisma yang sudah tertata dan juga memiliki cukup banyak kasus gizi kurang dan gizi buruk dalam beberapa tahun terakhir yaitu antara 2,3 sampai 3,2\% total balita. Penelitian ini merupakan penelitian eksperimental semu dengan rancangan pre and post test one group design. Subyek penelitian adalah 110 ibu balita yang berada pada 35 wilayah kerja Dawis dipilih secara purposive. Para dawis dibekali dengan alat penimbang berat badan dan pengukur tinggi badan. Hasil penelitian menunjukkan adanya perbedaan pengetahuan dan praktik ibu terkait gizi balita, setelah didampingi dawis selama 1 bulan $(\mathrm{p}<0,05)$, dengan uji wilcoxon match paired test. Penelitian ini dapat dipergunakan sebagai evidence based practice usulan program baru di bidang kesehatan, yaitu pendampingan Dawis sebagai salah satu program dalam pemantauan status gizi balita.
\end{abstract}

Kata kunci : Praktik ibu, status gizi, balita, pendampingan, dasa wisma

\section{ABSTRACT}

The incidence of malnutrition in Indonesia, also in Central Java and Semarang is still high, another problem is the lack of awareness and knowledge of the community including mother on monitoring nutritional status, and there has never been a group of community members who care about nutrition. The aim of this study was toanalyze changes in maternal attitudes and practices related to child nutrition after Dasawisma's assistance. The research was carried out in the work area of the Tlogosari Wetan Health Center in Semarang, on the grounds that the Puskesmas area has a number of Dasa Wisma that have been arranged and also have quite a number of cases of malnutrition and malnutrition in the last few years, namely between 2.3 to $3.2 \%$ of total under five.. This research was a quasi-experimental study, with a pre and post test one group design. The subjects of the study were 110 mothers of toddlers in 35 Dawis work areas, who were selected purposively, the Dawis were provided with a weight-bearing tool and a height gauge. The results showed differences in knowledge and practice regarding infant nutrition, after being accompanied by Dawis for 1 month $(p<0.05)$, with wilcoxon match paired test. This research can be used as evidence based practice on the proposed new program in the field of health, Dawis's assistance as a program in monitoring the nutritional status of children.

Keywords : Mother's practice, nutritional status, toddlers, activist assistance, dasa wisma 


\section{PENDAHULUAN}

Indeks pembangunan manusia (IPM) merupakan indikator untuk mengetahui keberhasilan pembangunan sumber daya manusia di suatu negara atau propinsi atau kota maupun kabupaten. IPM Indonesia masih berada di bawah negara-negara Asia Tenggara. Keberhasilan pembangunan nasional suatu bangsa lebih ditentukan oleh ketersediaan Sumber Daya Manusia (SDM) berkualitas, bukan oleh melimpahnya Sumber Daya Alam (SDA). Faktor utama yang berpengaruh terhadap kualitas SDM antara lain faktor genetik dan faktor lingkungan. Faktor genetik merupakan modal dasar dalam mencapai hasil akhir pertumbuhan dan perkembangan anak. Lingkungan merupakan faktor yang sangat menentukan tercapai atau tidaknya potensi bawaan. Status gizi yang baik, stimulasi dari keluarga, perumahan memadai, sanitasi lingkungan sehat serta tersedianya sarana dan prasarana akan menunjang pertumbuhan dan perkembangan anak yang nantinya merupakan calon sumber daya manusia. Perkembangan kecerdasan anak dapat terganggu oleh kondisi lingkungan atau fisik yang kurang mendukung, seperti kekurangan gizi/malnutrisi dan stimulasi dari lingkungan. Malnutrisi pada janin sampai usia dua tahun akan memiliki dampak jangka pendek dan jangka panjang. Dampak jangka pendeknya adalah akan terhambatnya pertumbuhan dan perkembangan otak anak, sehingga untuk jangka panjang akan menyebabkan rendahnya kemampuan berfikir dan kemampuan belajarnya. ${ }^{1}$

Salah satu cara yang efektif untuk memantau status gizi balita adalah dengan menggunakan KMS (Kartu Menuju Sehat). KMS adalah kartu yang memuat kurva pertumbuhan normal anak berdasarkan indeks antropometri berat badan menurut umur. KMS dapat bermanfaat dalam mengetahui lebih dini gangguan pertumbuhan atau risiko kelebihan gizi, sehingga dapat dilakukan tindakan pencegahan secara lebih cepat dan tepat sebelum masalahnya lebih berat. ${ }^{2} \mathrm{KMS}$ juga merupakan alat yang sederhana dan murah, yang dapat digunakan untuk memantau kesehatan dan pertumbuhan anak. KMS harus disimpan oleh ibu balita di rumah dan harus selalu dibawa setiap kali mengunjungi posyandu atau fasilitas pelayanan kesehatan termasuk bidan atau dokter. ${ }^{3}$ Kartu menuju sehat berfungsi sebagai alat bantu peman- tauan gerak pertumbuhan, bukan penilaian status gizi. KMS yang diedarkan Departemen Kesehatan Republik Indonesia sebelum tahun 2000, garis merah pada KMS versi tahun 2000 bukan merupakan pertanda gizi buruk, melainkan garis kewaspadaan. Berat badan balita yang tergelincir di bawah garis ini, petugas kesehatan harus melakukan pemeriksaan lebih lanjutan terhadap indikator antropometri klain. Catatan pada KMS dapat menunjukkan status gizi balita. Balita dengan pemenuhan gizi yang cukup memiliki berat badan yang berada pada daerah berwarna hijau, sedangkan warna kuning menujukkan status gizi kurang, dan jika berada di bawah garis merah menunjukkan status gizi buruk. ${ }^{4}$ Penyimpangan kurva pertumbuhan anak pada KMS balita biasanya menuju ke arah bawah, dan tidak banyak yang keluar dari warna hijau ke arah atas. Kurva pertumbuhan anak yang baik kesehatannya, akan terus terdapat dalam jalur hijau. Anak yang di bawah warna hijau, yaitu warna kuning, maka menunjukkan Kurang Kalori Protein (KKP) ringan dan menggambarkan adanya gangguan pertumbuhan ringan serta gangguan kesehatan. Keadaan anak yang lebih jelek lagi, yaitu garis pertumbuhan anak akan lebihmenurun lagi masuk ke daerah di bawah garis merah, yang merupakan batas bawah dari jalur kuning yang menunjukkan balita mengalami KKP berat. Anak sudah menderita gizi kurang atau terganggu kesehatannya. ${ }^{5}$ Status pertumbuhan anak dapat diketahui dengan dua cara yaitu dengan menilai garis pertumbuhannya, atau dengan menghitung kenaikan berat badan anak dibandingkan dengan kenaikan berat badan minimum. ${ }^{6}$ Pemantauan pertumbuhan dan perkembangan balita di posyandu dengan menggunakan KMS, akan berguna apabila dilakukan setiap bulan.

Hasil studi situasi dan analisis gizi di Indonesia tahun 2015, status Gizi Balita menurut Indeks Berat Badan per Umur (BB/U), didapatkan 14,9\% mengalami gizi kurang dan 3,8\% gizi buruk. Status Gizi Balita menurut Indeks Tinggi Badan per Usia (TB/U), didapatkan $29,9 \%$ balita pendek dan sangat pendek. Status Gizi Balita menurut Indeks Berat Badan per Tinggi Badan (BB/TB), didapatkan $8,2 \%$ kurus dan 3,7\% sangat kurus. Selain hasil tersebut berdasarkan pemantauan terakhir Sub Dit Gizi Kemenkes RI tahun 2017 masih ada 1487 balita mengalami Gizi buruk. ${ }^{7}$ Hasil Riskesdas 
2013 menunjukkan prevalensi gizi kurang pada balita(BB/U<-2SD) memberikan gambaran yang fluktuatif dari $18,4 \%$ (2007) menurun menjadi $17,9 \%$ (2010) kemudian meningkat lagi menjadi $19,6 \%$ (tahun 2013). Secara nasional, prevalensi berat-kurang $(\mathrm{BB} / \mathrm{U})$ terlihat meningkat. Perubahan terutama pada prevalensi gizi buruk, yaitu dari $5,4 \%$ tahun $2007,4,9 \%$ pada tahun 2010 , dan $5,7 \%$ tahun 2013. Sedangkan prevalensi gizi kurang naik sebesar $0,9 \%$ dari 2007 dan 2013. Prevalensi pendek secara nasional tahun 2013 adalah $37,2 \%$, yang berarti terjadi peningkatan dibandingkan tahun 2010 (35,6\%) dan 2007(36,8\%). Prevalensi pendek sebesar $37,2 \%$ terdiri dari $18,0 \%$ sangat pendek dan $19,2 \%$ pendek (stunting). ${ }^{8}$

Berdasarkan data Riskesdas tahun 2013, di Jawa Tengah didapatkan 5,2\% bayi dengan BBLR/kurang dari 2500 gram serta Panjang Badan kurang dari $47 \mathrm{~cm}$, sedangkan Kota Semarang 2,6\%. Status Gizi buruk di Jawa Tengah sebesar $4,1 \%$ dan gizi kurang $13,5 \%$; sedangkan Kota Semarang 3,7\% status gizi buruk dan 8,7\% status gizi kurang. ${ }^{9}$ Hasil pemantauan menunjukkan alasan balita tidak datang ke Posyandu karena berbagai alasan antara lain anak tidak mau ditimbang, anak sudah besar ( $\geq 1$ tahun), anak sudah selesai imunisasi, lupa/tidak tahu jadwalnya, tidak ada tempat penimbangan yang buka terus, tempat jauh dan orang tua sibuk pada saat jam Posyandu.

Tercapai tidaknya pemecahan masalah gizi di Indonesia sangat dipengaruhi banyak faktor, diantaranya adalah kemiskinan, kesehatan, pangan, pendidikan, air bersih, keluarga berencana, dan faktor lainnya. Oleh karena itu, upaya perbaikan gizi masyarakat memerlukan kerjasama banyak pihak dari berbagai sektor yang membutuhkan sinergi dan harus terkoordinasi dengan baik. Dengan adanya sistem desentralisasi setiap daerah memiliki kewenangan dalam mengatur upaya promotif dan preventif dalam mencegah adanya malnutrisi di tingkat masyarakat. Adanya sistem desentralisasi dalam pengelolaan wilayah membuka kesempatan dan peluang yang besar bagi Pemerintah Daerah dan jajarannya untuk membantu segala upaya dalam mencapai target tersebut. Upaya preventif yang dapat dilakukan oleh Pemerintah daerah adalah secara bersama-sama memperbaiki semua hal yang berkaitan dengan mata rantai terjadinya malnutrisi, dengan melibatkan semua sektor yang terkait.

Berdasarkan latar belakang tersebut maka perlu ada tindakan segera yang di luar program (out of the box) serta melibatkan pemberdayaan masyarakat. Selama ini pemberdayaan masyarakat sebagian besar difokuskan kepada kader kesehatan. Pendampingan atau pemantauan terkait status gizi oleh kader sudah banyak dilaksanakan, padahal tokoh masyarakat yang paling dekat dengan keluarga adalah Dasa Wisma, sekitar 10 keluarga berada dalam perkumpulan Dasa Wisma yang di pimpin oleh seorang Ketua atau Aktivis Dasa Wisma. Pemberian intervensi berupa pelatihan dengan media modul dapat digunakan untuk menyampaikan materi pendidikan tentang penentuan status gizi, dengan metode simulasi para anggota masyarakat yang dilatih sebagai pendamping dapat meniru, memeragakan ulang segala sesuatu yang berkaitan dengan materi yang disampaikan, metode ini bertujuan untuk melatih dan memahami konsep atau prinsip dari pendidikan yang disampaikan sehingga dapat memecahkan masalah terkait malnutrisi. Pendampingan berupa edukasi tentang nutrisi anak balita, cara pemantauan status gizi dan praktik efektif dalam upaya menurunkan risiko kejadian malnutrisi pada anak balita, terutama stunting.

Permasalahan dalam penelitian ini adalah masih tingginya kejadian malnutrisi di Indonesia, juga di Jawa Tengah dan Kota Semarang, sedangkan di sisi lain Indonesia memiliki target di bidang perbaikan gizi masyarakat. Target tersebut, diantaranya adalah menurunnya prevalensi kekurangan gizi pada anak balita, dari 19,6\% menjadi $17 \%$ pada tahun 2019 ; dan menurunnya prevalensi stunting pada anak di bawah 2 tahun, dari $33 \%$ menjadi $28 \%$ pada tahun 2019 . Permasalahan lain lagi adalah masih kurangnya kesadaran dan pengetahuan masyarakat termasuk aktivis dasa wisma tentang gizi. Aktivis Dasa Wisa (Dawis) merupakan kader kesehatan yang memiliki tanggung jawab memberikan edukasi dan pemantauan kesehatan atas sepuluh keluarga di suatu wilayah. Padahal masyarakatlah yang semestinya memiliki kesadaran bahwa gizi baik adalah kebutuhan mereka sendiri. Penelitian ini sebagai Pilot Project dilakukan di wilayah kerja puskesmas Tlogosari Wetan Kota Semarang, dengan alasan wilayah puskesmas tersebut memiliki sejumlah Dasa Wis- 
ma yang sudah tertata dan juga memiliki cukup banyak kasus gizi kurang dan gizi buruk dalam beberapa tahun terakhir yaitu antara 2,3 sampai $3,2 \%$ total balita. Tujuan dari penelitian ini adalah untuk menganalisis perubahan sikap dan praktik dari ibu terkait gizi balita setelah pendampingan aktivis dawis.

\section{BAHAN DAN METODE}

Penelitian ini merupakan penelitian eksperimental semu, dengan rancangan pre and post test one group design yang dilaksanakan pada bulan April sampai dengan Agustus 2018. Penelitian dilakukan di wilayah kerja Puskesmas Tlogosari Wetan Kota Semarang. Subyek penelitian adalah 110 ibu balita yang berada di bawah pendampingan 35 aktivis dasa wisma dengan kriteria ada balita di wilayah kerjanya (purposive sampling), yang nantinya akan diukur perubahan perilaku (pengetahuan dan praktik) terkait pemantauan status gizi, dibandingkan sebelum dan sesudah diberikan intervensi pendampingan aktivis dasa wisma selama satu bulan. Pendampingan berupa edukasi tentang nutrisi anak balita, cara pemantauan status gizi dan praktik efektif dalam upaya menurunkan risiko kejadian malnutrisi pada anak balita, terutama stunting. Sebelumnya para aktivis dasa wisma dilatih terlebih dahulu dengan bekal buku pendampingan dan dibekali sarana alat penimbang berat badan dan pengukur tinggi badan. Apabila terbukti ada perubahan perilaku para ibu balita dalam pemantauan status gizi balita, maka penelitian ini dapat dipergunakan sebagai evidence based practice usulan program baru di bidang kesehatan, yaitu pemberian pelatihan pemantauan status gizi balita serta pendampingan aktivis dasa wisma sebagai salah satu program andalan dalam menurunkan malnutrisi balita, terutama stunting. Pelatihan pendampingan dilakukan oleh Tim Gizi dari Fakultas Kesehatan Masyarakat selama 2 hari penuh dengan metode pelatihan, diskusi, praktik pengukuran dan identifikasi status gizi, serta role play. Bentuk pendampingan dilakukan oleh Ajtivis atau Kadawis yang sudah dilatih, pada para ibu bayi dan balita yang ada di wilayahnya terkait pemantauan status gizi balita, selama sekitar 1 bulan penuh. Dalam satu bulan ibu dikunjungi dan diminta untuk mendatangi Rumah Kadawis untuk belajar mengukur serta mengintepretasikan status gizi balita masing-masing.

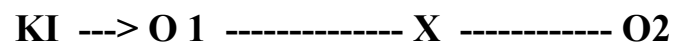

Keterangan:

KI : Kelompok intervensi yang terdiri dari 110 Ibu Balita

O1 : Pengukuran skor awal (pretest) sebelum diberi intervensi, yang diukur adalah variabel pengetahuan dan praktik Ibu Balita terkait Pemantauan Status Gizi Balita (PSGB)

$\mathrm{X}$ : Pemberian pendampingan pada Ibu Balita oleh KaDawis terkait pemantauan status gizi balita (PSGB),selama satu bulan

O2 : Pengukuran skor akhir (posttest) setelah diberi intervensi, yang diukur adalah variabel pengetahuan dan praktik Ibu balita terkait Pemantauan Status Gizi Balita (PSGB), sekitar sebulan setelah intervensi, oleh enumerator terlatih

Analisis dan penyajian data dilakukan secara univariat dan bivariat. Bivariat dengan uji analisis yaitu wilcoxon match paired test karena data tidak berdistribusi normal. Data terdiri dari berbagai pertanyaan mengenai pengetahuan dan praktik ibu balita terkait dengan pemantauan dan penatalaksanaaan status gizi balita. Etical clearance didapat dari komisi etik Penelitian Kesehatan Fakultas Kesehatan Masyarakat Universitas Diponegoro 225/EA/KEPK-FKM/2018.

\section{HASIL}

Hasil penelitian ini menunjukkan dari total 110 responden penelitian ini, berdasarkan Tabel 1 didapatkan sebagian besar ibu balita berusia antara 20 - 35 tahun (70.9\%) dengan usia 28 tahun terdiri dari 12 orang $(10,9 \%)$, pekerjaan 70 ibu balita yaitu sebagai ibu rumah tangga (63.6\%), pendidikan terakhir ibu balita, sebagian besar pendidikan terakhir adalah SMA yaitu sejumlah 34 ibu balita $(55,8 \%)$ dan sederajatnya-SMK sejumlah $15 \mathrm{ibu}$ balita (13.6\%), sebagian besar usia balita yaitu antara usia 1-1.11 tahun sejumlah 29 balita (26.4\%), selain itu paling banyak ibu balita dengan jumlah anak 2 (46 ibu balita atau 41.8\%), dan ibu balita paling banyak mempunyai 6 anak walaupun jumlahnya hanya $1(0.9 \%)$.

Setelah intervensi menunjukkan bahwa ada 
Tabel 1. Karakteristik Responden

\begin{tabular}{|c|c|c|}
\hline Karakteristik & $n=110$ & $\%$ \\
\hline \multicolumn{3}{|l|}{ Usia ibu balita } \\
\hline Kurang dari 20 tahun & 1 & 0.9 \\
\hline $20-35$ tahun & 78 & 70.9 \\
\hline Lebih dari 35 tahun & 31 & 28.2 \\
\hline \multicolumn{3}{|l|}{ Pekerjaan } \\
\hline BLUD & 1 & 0.9 \\
\hline IRT & 70 & 63.6 \\
\hline PNS & 4 & 3.6 \\
\hline Swasta & 30 & 27.3 \\
\hline Wiraswasta & 5 & 4.5 \\
\hline \multicolumn{3}{|l|}{ Pendidikan ibu } \\
\hline $\mathrm{SD}$ & 9 & 8.2 \\
\hline SMP & 19 & 17.3 \\
\hline SMA & 34 & 30.9 \\
\hline D3 & 15 & 13.6 \\
\hline S1 & 11 & 10.0 \\
\hline $\mathrm{S} 2$ & 1 & 0.9 \\
\hline \multicolumn{3}{|l|}{ Usia balita } \\
\hline 0-11 bulan & 16 & 14.5 \\
\hline 1-1.11 tahun & 29 & 26.4 \\
\hline $2-2.11$ tahun & 20 & 18.2 \\
\hline 3-3.11 tahun & 20 & 18.2 \\
\hline 4-5 tahun & 25 & 22.7 \\
\hline \multicolumn{3}{|l|}{ Jumlah anak } \\
\hline 1 & 35 & 31.8 \\
\hline 2 & 46 & 41.8 \\
\hline 3 & 24 & 21.8 \\
\hline 4 & 3 & 2.7 \\
\hline 5 & 1 & 0.9 \\
\hline 6 & 1 & 0.9 \\
\hline
\end{tabular}

perbedaan pengetahuan ibu balita sebelum dan sesudah dilakukan intervensi berupa pendampingan oleh aktivis dasa wisma tentang gizi anak balita pada Tabel 2, terdapat peningkatan pengetahuan, hal tersebut terlihat dengan adanya beberapa pengurangan ketidaktahuan akan status gizi pada anak setelah intervensi, diantaranya pertanyaan terkait arti KMS, sebagian besar responden (95.5\%) telah mengetahuinya, dan setelah diadakannya pendampingan oleh dawis semua responden sudah mengetahui arti KMS yang dapat digunakan sebagai alat pemantau kecukupan gizi balita $(100 \%)$. Korelasi terkait garis merah pada KMS dengan kecukupan gizi balita, sebagian besar responden $(77,3 \%)$ telah mengetahuinya, setelah diadakannya pendampingan oleh dawis ada peningkatan jumlah responden lebih dari $10 \%$ yang mengetahui terkait berat badan balita berada di atas garis merah pada KMS merupakan salah satu tanda balita cukup gizi $(89,1 \%)$.

Untuk berat badan balita dengan pertumbuhan anak balita, sebagian besar responden (90.9\%) telah mengetahuinya, setelah diadakannya pendampingan oleh dawis ada peningkatan jumlah responden yang mengetahui terkait berat badan balita yang naik dibandingkan sebelumnya berarti status pertumbuhan anak balita itu baik (97.3\%). Hubungan bawah garis merah pada KMS dengan kecukupan gizi balita, sebagian besar responden $(79,1 \%)$ telah mengetahuinya, setelah diadakannya pendampingan oleh dawis ada peningkatan jumlah responden cukup signifikan yang mengetahui terkait berat badan balita dibawah garis merah pada KMS menandakan ibu balita perlu mengkhawatirkan nya $(93,6,0 \%)$. Terkait manfaat KMS, sebagian besar responden $(95,5 \%)$ telah mengetahuinya, setelah diadakannya pendampingan oleh dawis ada peningkatan jumlah responden yang mengetahui terkait dari manfaat KMS adalah untuk mengetahui pertumbuhan anak balita $(99,1 \%)$.

Pemenuhan ASI sebagai makanan terbaik bayi usia 0-6 bulan, sebagian besar responden (89.1\%) telah mengetahuinya, setelah diadakannya pendampingan oleh dawis ada peningkatan jumlah responden yang mengetahui tentang ASI adalah makanan terbaik bayi usia 0-6 bulan (93.6\%). Fenomena ASI yang keluar pertama kali (colostrum), sebagian besar responden (97.3\%) telah mengetahuinya, setelah diadakannya pendampingan oleh dawis semua responden sudah mengetahui bahwa ASI yang keluar pertama kali tidak dibuang karena mengandung kolostrum yang sangat baik untuk kekebalan tubuh bayi (100\%). Proses pemberian MP-ASI secara bertahap, sebagian besar responden $(98.2 \%)$ telah mengetahuinya, setelah diadakannya pendampingan oleh dawis ada peningkatan jumlah responden yang mengetahui tentang pemberian makanan pendamping ASI yang harus dilakukan secara bertahap dimulai dari makanan lumat, lunak sampai makanan padat seperti orang dewasa (99.1\%).

Pada topik terkait makanan padat setelah usia 1 tahun, sebagian besar responden $(94,5 \%)$ telah mengetahuinya, setelah diadakannya pendampingan oleh dawis ada peningkatan jumlah responden yang mengetahui tentang hal anak yang baru bisa makan dengan makanan-makanan padat 
Tabel 2. Perbedaan Pengetahuan Responden Sebelum dan Sesudah Intervensi

\begin{tabular}{|c|c|c|c|c|c|c|c|c|}
\hline \multirow{3}{*}{ Pernyataan } & \multicolumn{4}{|c|}{ Sebelum Intervensi } & \multicolumn{4}{|c|}{ Setelah Intervensi } \\
\hline & \multicolumn{2}{|c|}{ Tahu } & \multicolumn{2}{|c|}{ Tidak Tahu } & \multicolumn{2}{|c|}{ Tahu } & \multicolumn{2}{|c|}{ Tidak Tahu } \\
\hline & $\mathbf{n}$ & $\%$ & $\mathbf{n}$ & $\%$ & $\mathbf{n}$ & $\%$ & $\mathbf{n}$ & $\%$ \\
\hline Kartu Menuju Sehat (KMS) & 105 & 95.5 & 5 & 4.5 & 110 & 100 & 0 & 0,0 \\
\hline Arti atas Garis Merah pada KMS & 85 & 77.3 & 25 & 22.7 & 98 & 89.1 & 12 & 10.9 \\
\hline Pertumbuhan anak balita & 100 & 90.9 & 10 & 9.1 & 107 & 97.3 & 3 & 2.7 \\
\hline Arti Bawah Garis Merah KMS & 87 & 79.1 & 23 & 20.9 & 103 & 93.6 & 7 & 6.4 \\
\hline Manfaat KMS & 105 & 95.5 & 5 & 4.5 & 109 & 99.1 & 1 & 0.9 \\
\hline $\begin{array}{l}\text { ASI adalah makanan terbaik bayi } \\
\text { usia } 0-6 \text { bulan }\end{array}$ & 98 & 89.1 & 12 & 10.9 & 103 & 93.6 & 7 & 6,4 \\
\hline ASI yang keluar pertama kali & 107 & 97.3 & 3 & 2.7 & 110 & 100.0 & 0 & 0,0 \\
\hline Pemberian MPASI secara bertahap & 108 & 98.2 & 2 & 1.8 & 109 & 99.1 & 1 & 0.9 \\
\hline $\begin{array}{l}\text { Makanan padat setelah usia } 1 \\
\text { Tahun }\end{array}$ & 104 & 94.5 & 6 & 5.5 & 105 & 95.5 & 5 & 4.5 \\
\hline $\begin{array}{l}\text { Pembedaan pengelolaan makanan } \\
\text { balita dengan keluarga }\end{array}$ & 104 & 94.5 & 6 & 5.5 & 108 & 98.2 & 2 & 1.8 \\
\hline Frekuensi makan balita 1-5 Tahun & 105 & 95.5 & 5 & 4.5 & 109 & 99.1 & 1 & 0.9 \\
\hline Makanan beranekaragam & 108 & 98.2 & 2 & 1.8 & 110 & 100 & 0 & 0,0 \\
\hline
\end{tabular}

Tabel 3. Perbedaan Praktik Responden Sebelum dan Sesudah Intervensi

\begin{tabular}{|c|c|c|c|c|c|c|c|c|}
\hline \multirow{3}{*}{ Pernyataan } & \multicolumn{4}{|c|}{ Sebelum Intervensi } & \multicolumn{4}{|c|}{ Setelah Intervensi } \\
\hline & \multicolumn{2}{|c|}{ Melakukan } & \multicolumn{2}{|c|}{ Tidak Melakukan } & \multicolumn{2}{|c|}{ Melakukan } & \multicolumn{2}{|c|}{ Tidak Melakukan } \\
\hline & $\mathbf{n}$ & $\%$ & $\mathbf{n}$ & $\%$ & $\mathbf{n}$ & $\%$ & $\mathbf{n}$ & $\%$ \\
\hline Praktik penimbangan BB balita & 34 & 30.9 & 76 & 69,1 & 46 & 41.8 & 64 & 58.2 \\
\hline Praktik pengukuran TB balita & 14 & 12,7 & 96 & 87,3 & 23 & 20,9 & 87 & 79,9 \\
\hline Kartu Menuju Sehat (KMS) & 106 & 96.4 & 4 & 3.6 & 109 & 99.1 & 1 & 0.9 \\
\hline $\begin{array}{l}\text { Menjelaskan tentang hasil } \\
\text { penimbangan }\end{array}$ & 108 & 98.2 & 2 & 1.8 & 110 & 100 & 0 & 0,0 \\
\hline Memberikan buah pada balita & 108 & 98.2 & 2 & 1.8 & 108 & 98.2 & 2 & 1.8 \\
\hline $\begin{array}{l}\text { Memberikan susu (ASI/PASI) } \\
\text { pada balita }\end{array}$ & 109 & 99.1 & 1 & 0.9 & 110 & 100 & 0 & 0,0 \\
\hline $\begin{array}{l}\text { Pemberian makanan sesuai dengan } \\
\text { usia balita }\end{array}$ & 109 & 99.1 & 1 & 0.9 & 100 & 100 & 0 & 0,0 \\
\hline $\begin{array}{l}\text { Pemisahaan pengelolaan makanan } \\
\text { balita dengan keluarga }\end{array}$ & 107 & 97.3 & 3 & 2.7 & 107 & 97.3 & 3 & 2.7 \\
\hline $\begin{array}{l}\text { Ibu mempersiapkan makanan } \\
\text { untuk balitanya }\end{array}$ & 108 & 98.2 & 2 & 1.8 & 109 & 99.1 & 1 & 0.9 \\
\hline $\begin{array}{l}\text { Kebersihan tangan sebelum } \\
\text { menyuapi balita }\end{array}$ & 107 & 97.3 & 3 & 2.7 & 110 & 100.0 & 0 & 0,0 \\
\hline $\begin{array}{l}\text { Pemberian makanan balita } \\
\text { bervariasi setiap makan }\end{array}$ & 108 & 98.2 & 2 & 1.8 & 109 & 99.1 & 1 & 0.9 \\
\hline $\begin{array}{l}\text { Pemberian makanan pokok dengan } \\
\text { lauk }\end{array}$ & 106 & 96.4 & 4 & 3.6 & 109 & 99.1 & 1 & 0.9 \\
\hline Pemberian makanan tambahan lain & 109 & 99.1 & 1 & 0.9 & 109 & 99.1 & 1 & 110 \\
\hline
\end{tabular}

setelah usia anak diatas 1 tahun (95.5\%). Selain itu, terkait pembedaan pengelolaan makanan balita dengan keluarga, sebagian besar responden $(94,5 \%)$ telah mengetahuinya, setelah diadakan- nya pendampingan oleh dawis ada peningkatan jumlah responden yang mengetahui tentang hal pengelolaan makanan untuk balita yang seharusnya dibedakan dengan pengelolaan makanan un- 
Tabel 4. Perbedaan Skor Pengetahuan Ibu Balita Sebelum dan Sesudah Pendampingan oleh Dawis

\begin{tabular}{|c|c|c|c|c|}
\hline \multirow{2}{*}{ Pengetahuan Ibu Balita } & \multicolumn{2}{|c|}{ Sebelum Intervensi } & \multicolumn{2}{|c|}{ Sebelum Intervensi } \\
\hline & $\mathrm{n}$ & $\%$ & $\mathrm{n}$ & $\%$ \\
\hline Menjawab benar kurang dari atau sama dengan $75 \%$ & 6 & 5.5 & 1 & 0.9 \\
\hline Menjawab benar lebih dari $75 \%$ & 104 & 94.5 & 109 & 99.1 \\
\hline Total nilai & 110 & 100,0 & 110 & 100,0 \\
\hline Mean & \multicolumn{2}{|c|}{12.05} & \multicolumn{2}{|c|}{12.66} \\
\hline SD & \multicolumn{2}{|c|}{1.344} & \multicolumn{2}{|c|}{0.708} \\
\hline Delta & \multicolumn{2}{|c|}{0,61} & & \\
\hline Nilai skor minimal & \multicolumn{2}{|c|}{7} & \multicolumn{2}{|c|}{9} \\
\hline Nilai skor maksimal & & & \multicolumn{2}{|c|}{13} \\
\hline Uji Wilcoxon & \multicolumn{4}{|c|}{$\mathrm{p}=0,001(\mathrm{p}>0,05)$} \\
\hline
\end{tabular}

Tabel 5. Perbedaan Skor Praktik Ibu Balita Sebelum dan Sesudah Pendampingan oleh Dawis

\begin{tabular}{|c|c|c|c|c|}
\hline \multirow{2}{*}{ Praktik Ibu Balita } & \multicolumn{2}{|c|}{ Sebelum Intervensi } & \multicolumn{2}{|c|}{ Sebelum Intervensi } \\
\hline & $\mathrm{n}$ & $\%$ & $n$ & $\%$ \\
\hline Baik & 35 & 31.8 & 48 & 43.6 \\
\hline Kurang baik & 75 & 68.2 & 62 & 56.4 \\
\hline Total nilai & 110 & 100,0 & 110 & 100,0 \\
\hline Mean & \multicolumn{2}{|c|}{10.25} & \multicolumn{2}{|c|}{10.56} \\
\hline SD & \multicolumn{2}{|c|}{0.893} & \multicolumn{2}{|c|}{0.841} \\
\hline Delta & \multicolumn{2}{|c|}{0,31} & & \\
\hline Nilai skor minimal & \multicolumn{2}{|c|}{6} & \multicolumn{2}{|c|}{8} \\
\hline Nilai skor maksimal & & & \multicolumn{2}{|c|}{12} \\
\hline Uji Wilcoxon & \multicolumn{4}{|c|}{$\mathrm{p}=0,001(\mathrm{p}<0,05)$} \\
\hline
\end{tabular}

tuk keluarga $(98,2 \%)$. Frekuensi makan balita 1-5 tahun, sebagian besar responden $(95,5 \%)$ telah mengetahuinya, setelah diadakannya pendampingan oleh dawis ada peningkatan jumlah responden yang hampir semua mengetahui tentang hal balita berusia 1-5 tahun makan makanan utama sebanyak 3 kali sehari ditambah makanan selingan diantara setiap makanan utama $(99,1 \%)$. Kebutuhan makanan beranekaragam, sebagian besar responden $(98.2 \%)$ telah mengetahuinya, setelah diadakannya pendampingan oleh dawis semua responden sudah mengetahui tentang makanan yang diberikan pada anak sebaiknya makanan yang beranekaragam dan bervariasi $(100 \%)$.

Setelah intervensi menunjukkan bahwa ada perbedaan pengetahuan ibu balita sebelum dan sesudah dilakukan intervensi berupa pendampingan oleh aktivis dasa wisma tentang gizi anak balita pada Tabel 3, terdapat peningkatan praktik setelah intervensi, diantaranya penilaian praktik penimbangan berat badan balita oleh ibu secara benar, hampir sepertiga responden $(30,9 \%)$ telah dapat melakukan, setelah diadakannya pendampingan oleh dawis ada peningkatan jumlah responden yang dapat melakukan penimbangan berat badan balita dengan benar (41.8\%). Praktik penilaian praktik pengukuran tinggi badan balita oleh ibu secara benar, sebagian kecil responden $(12,7 \%)$ telah dapat melakukan, setelah diadakannya pendampingan oleh dawis ada peningkatan jumlah responden yang dapat melakukan pengukuran tinggi badan balita dengan benar (20,9\%). Penggunaan KMS untuk melihat kenaikan berat badan, hampir semua responden $(96,4 \%)$ telah dapat melakukan, setelah diadakannya pendampingan oleh dawis ada peningkatan jumlah responden yang melakukan penilaian kenaikan berat badan balita dikartu KMS (99,1\%). Kemampuan ibu balita menjelaskan hasil penimbangan, hampir semua responden $(98,2 \%)$ telah dapat melakukan, setelah diadakannya pendampingan oleh dawis semua responden yang dapat menjelaskan hasil penimbangan (100\%). Praktik memberikan buah pada balita, hampir semua responden $(98,2 \%)$ sudah membe- 
rikannya, setelah diadakannya pendampingan oleh dawis tidak ada peningkatan jumlah responden yang memberikan buah pada balita untuk dikonsumsi $(98,2 \%)$.

Praktik memberikan susu (ASI/PASI) pada balita, hampir semua responden $(99,1 \%)$ sudah melakukan, setelah diadakannya pendampingan oleh dawis ada peningkatan, yaitu semua responden memberikan susu (ASI/PASI) kepada balita setiap hari $(100,0 \%)$. Pemberian makanan sesuai dengan usia balita, hampir semua responden $(99,1 \%)$ sudah melakukan, setelah diadakannya pendampingan oleh dawis ada peningkatan yaitu semua responden memberikan makanan sesuai dengan usia balitanya $(100,0 \%)$. Pemisahan pengelolaan makanan balita dengan keluarga, hampir semua responden $(97,3 \%)$ telah melakukan, setelah diadakannya pendampingan oleh dawis tidak ada peningkatan jumlah responden yang melakukan pemisahan pengelolaan makanan balita dengan anggota keluarga lainnya oleh ibu balita $(97,3 \%)$. Ibu mempersiapkan makanan untuk balitanya, hampir semua responden $(98,2 \%)$ telah melakukan, setelah diadakannya pendampingan oleh dawis ada peningkatan jumlah responden yang mempersiapkan sendiri makanan untuk anak balitanya $(99,1 \%)$.

Mengenai kebersihan tangan sebelum menyuapi balita, hampir semua responden $(97,3 \%)$ telah melakukan, setelah diadakannya pendampingan oleh dawis ada peningkatan jumlah responden yaitu semua responden melakukan cuci tangan sebelum menyuapi balita dan mencuci tangan dengan air mengalir serta sabun hingga besih $(100,0 \%)$. Pemberian makanan balita yang bervariasi, sebagian besar responden $(98,2 \%)$ telah melakukan, setelah diadakannya pendampingan oleh dawis ada peningkatan jumlah responden yang melakukan terkait pemberian makanan balita yang bervariasi dari pagi hingga sore hari (99,1\%). Pemberian makanan pokok dengan lauk, sebagian besar responden $(96,4 \%)$ sudah melakukannya, setelah diadakannya pendampingan oleh dawis ada peningkatan jumlah responden, yaitu hampir semua responden melakukan pemberian makanan pokok nasi atau karbohidrat lainnya kepada balita selalu menambahkan lauk pauk seperti tempe, telur, dan sayuran $(99,1 \%)$. Pemberian makanan tambahan lain, 99,1\% responden sudah melakukan, setelah diadakannya pendampingan oleh dawis semua responden sudah melakukan pemberian makanan tambahan lain (kacang hijau, kue, dan lainnya) selain makanan pokok pada balita $(100 \%)$.

Perbedaan total skor pengetahuan sebelum dan sesudah pendampingan oleh dawis pada Tabel 4. Hasil uji normalitas didapatkan variabel pre test tidak berdistribusi normal $(p=0,001)$ dan variabel post test tidak berdistribusi normal $(\mathrm{p}=0,001)$, sehingga kemudian dipilih uji wilcoxon. Dari hasil uji beda dengan uji wilcoxon $(\mathrm{p}=0,0001)$ yang berarti ada perbedaan atau terdapat perbedaan pengetahuan yang bermakna antara sebelum intervensi dengan sesudah intervensi. Sehingga disimpulkan ada pengaruh pendampingan dawis terhadap pengetahuan ibu terkait dengan penatalaksanaan gizi balita di wilayah kerja Puskesmas Tlogosari Wetan.

Perbedaan total skor praktik sebelum dan sesudah pendampingan oleh dawis pada Tabel 5. Hasil uji normalitas didapatkan variabel pre test berdistribusi normal $(\mathrm{p}=0,001)$ dan variabel post test tidak berdistribusi normal $(\mathrm{p}=0,001)$, sehingga dipilih uji beda menggunakan uji wilcoxon. Dari hasil uji beda dengan uji wilcoxon $(\mathrm{p}=0,0001)$ yang berarti ada perbedaan atau terdapat perbedaan praktik yang bermakna antara sebelum intervensi dengan sesudah intervensi. Sehingga disimpulkan ada pengaruh pendampingan dawis terhadap praktik ibu terkait dengan penatalaksanaan gizi balita di wilayah kerja Puskesmas Tlogosari Wetan.

\section{PEMBAHASAN}

Konsep intervensi berupa pendampingan oleh aktivis dasa wisma tentang gizi anak balita kepada ibu balita. Sebelumnya para aktivis dasa wisma dilatih dulu dengan bekal buku pendampingan dan dibekali sarana alat penimbang berat badan dan pengukur tinggi badan, selanjutnya para aktivis dasa wisma memberikan pendampingan kepada ibu balita selama satu bulan. Bentuk pendampingan berupa edukasi tentang gizi anak balita, cara menentukan status gizi dan praktik dalam upaya menurunkan risiko kejadian malnutrisi pada anak balita, terutama stunting. Setelah intervensi menunjukkan bahwa ada perbedaan pengetahuan ibu balita sebelum dan sesudah dilakukan intervensi berupa pendampingan oleh aktivis dasa 
wisma tentang gizi anak balita dengan $\mathrm{p}=0,001$ dengan peningkatan nilai rerata sebesar 0,61 poin. Peningkatan pengetahuan terutama pada pengetahuan tentang pertumbuhan balita di KMS serta arti makna status gizi dibawah dan diatas garis merah. Pemberian ASI eksklusif serta ASI yang pertama keluar, dan pengelolaan makan balita dalam keluarga. Selain itu, ada perbedaan praktik ibu balita sebelum dan sesudah dilakukan intervensi berupa pendampingan oleh aktivis dasa wisma tentang gizi anak balita dengan $p=0,001$, dengan peningkatan nilai rerata sebesar 0,31 poin. Peningkatan praktik terutama pada praktik penimbangan berat badan dan pengukuran tinggi badan, intepretasi pembacaaan KMS serta praktik cuci tangan sebelum menyuapi balita.

Temuan pengaruh intervensi berupa pendampingan oleh aktivis dasa wisma tentang gizi anak balita pada penelitian ini sejalan dengan penelitian terdahulu yang menemukan bahwa pada program partisipasi dalam pendidikan gizi gabungan dan program pemberian makan tambahan di Uganda menunjukkan beberapa manfaat tentang gizi anak balita dan yang terkait kecukupan diet anak-anak, satu sampai 3 bulan setelah intervensi pemberian makanan tambahan dihentikan. Kelompok intervensi memiliki skor keragaman diet yang lebih tinggi $(3,0$ vs $2,1, \mathrm{p}=0,001)$ dari kelompok kontrol, dan diberi makan lebih sering ( 3,0 vs 2,1 kali per hari, $p=0,001)$, frekuensi makan minimum $(44,8 \%$ vs $37,9 \%)$, keragaman diet minimum $(10,3 \%$ vs $3,4 \%)$. Pendidikan nutrisi dapat efektif untuk meningkatkan pengetahuan, praktik pemberian makanan anak balita, meningkatkan keragaman dan frekuensi makanan anak balita. ${ }^{10}$

Beberapa penelitian berkelanjutan mengenai dampak dari program edukasi nutrisi yang mirip dengan yang dinilai dalam penelitian ini. Sebuah uji coba edukasi pemberian makanan tambahan bagi anak balita di Malawi yang memberikan empat poin edukasi nutrisi menunjukkan adanya peningkatan penerapan praktik yang pemberian makanan tambahan oleh orang tua maupun perawat (caregiver). ${ }^{11}$ Sebuah uji coba secara acak di Laishui, China yang memberikan edukasi nutrisi dan pemberian makanan tambahan melalui pelatihan kelompok dan kunjungan rumah selama 2-4 bulan menemukan bahwa ibu yang ditugaskan ke kelompok intervensi menunjukkan perubahan substan- sial dalam pemberian makanan pendamping ASI, dan anak balita menunjukkan pertumbuhan yang lebih baik setelah dilakukan kontrol selama satu tahun. ${ }^{12}$ Intervensi pada sebuah kajian di Haryana, India mengenai pemberian makanan pendamping ASI dan konseling nutrisi untuk ibu dari bayi baru lahir, menunjukkan bahwa asupan energi dan kenaikan panjang badan secara signifikan membaik, walaupun berat badan tidak, dibandingkan dengan kelompok kontrol. ${ }^{13}$ Daerah pedesaan Ethiopia dengan prevalensi stunting yang tinggi, paparan intervensi pendidikan gizi pada ibu balita terbukti efektif dalam meningkatkan pengetahuan tentang praktik nutrisi anak balita dan mencegah tumbuh kerdil (stunting). ${ }^{14}$ Dengan demikian, edukasi nutrisi dalam bentuk pendampingan oleh aktivis dasa wisma kepada ibu balita bisa menjadi metode yang efektifuntuk meningkatkan pengetahuan dan praktik mandiri ibu balita dalam pemenuhan nutrisi, pemantauan status gizi, dan tercapainya status gizi optimal bagi anak balita, bahkan di daerah yang rawan pangan tinggi dan keterbatasan ekonomi.

Sebagian besar responden dengan pendidikan terakhir SMA, yaitu sejumlah 34 (30,9\%), hal ini sejalan dengan penelitian Rahmariza et al. menyebutkan bahwa pemenuhan hak kesehatan, termasuk nutrisi pada anak dipengaruhi oleh pendidikan ibu sebesar $17.40 \%$, terdapat hubungan yang positif antara pendidikan ibu dengan pengetahuan gizi, kesehatan, dan pengasuhan anak. Ibu dengan pendidikan yang tinggi cenderung memiliki pengetahuan gizi, kesehatan, dan pengasuhan anak yang baik. ${ }^{15}$ Pengetahuan ibu mengenai nutrisi bagi anak adalah landasan penting untuk mencukupi intake gizi anak. Pengetahuan gizi yang diimplementasikan dalam sikap dan praktik yang akan mendorong terbentuk pola makan yang baik di dalam rumah tangga. ${ }^{16}$ Tingkat pendidikan yang lebih tinggi anak memudahkan seseorang menyerap informasi dan mengimplementasikannya ke dalam perilaku dan gaya hidup sehari-hari, khususnya dalam hal kesehatan dan gizi. Tingkat pendidikan, khususnya tingkat pendidikan wanita mempengaruhi derajat kesehatan. ${ }^{17}$

Pemenuhan status gizi anak balita sangat penting dilaksanakan, hal ini sejalan dengan kajian Davidson et al. yang menunjukkan bahwa morbiditas dan status gizi saling memengaruhi. Status gizi pada anak di bawah lima tahun me- 
rupakan dasar dari tingginya morbiditas. ${ }^{18}$ Status gizi yang kurang baik akan menyebabkan daya tahan tubuh menurun dan mudah terserang penyakit infeksi. Begitupun sebaliknya bahwa terserang penyakit infeksi mengganggu metabolisme zatzat gizi di dalam tubuh sehingga pemanfaatan zat gizi di dalam tubuh menjadi tidak optimal dan akanberdampak pertumbuhan. ${ }^{19}$ Hasil uji korelasi dalam kajian Davidson et al. ditemukan bahwa densitas asupan energi signifikan berhubungan dengan status gizi $\mathrm{BB} / \mathrm{U}(\mathrm{p}=0,043 ; \mathrm{r}=0,185)$ dan status gizi $\mathrm{BB} / \mathrm{TB}(\mathrm{p}=0,005 ; \mathrm{r}=0,254)$. Semakin tinggi densitas asupan energi seseorang maka nilai $z$-score status gizi $\mathrm{BB} / \mathrm{U}$ danBB/TB akan semakin meningkat. Densitas asupan energi tidak signifkan berhubungan dengan status gizi $\mathrm{TB} / \mathrm{U}(\mathrm{p}=0,956$; $\mathrm{r}=0,005)$. Densitas asupan protein signifikan berhubungan dengan status gizi TB/U ( $\mathrm{p}=0,000$; $\mathrm{r}=0,354)$ dan status gizi $\mathrm{BB} / \mathrm{U}(\mathrm{p}=0.000 ; \mathrm{r}=0,378)$, tetapi tidak signifikan berhubungan dengan status gizi $\mathrm{BB} / \mathrm{TB}(\mathrm{p}=0,505 ; \mathrm{r}=0,061)$. Semakin tinggi densitas asupan protein maka status gizi $\mathrm{TB} / \mathrm{U}$ dan $\mathrm{BB} / \mathrm{U}$ anak semakinbaik. ${ }^{18}$ Dengan demikian, edukasi nutrisi dengan materi edukasi frekuensi makan optimal, pemberian makanan beranekaragam, pemberian makanan tambahan lain efektif dalam upaya mengoptimalkan status gizi anak balita.

\section{KESIMPULAN DAN SARAN}

Pendampingan berupa edukasi tentang nutrisi anak balita, cara pemantauan status gizi dan praktik efektif dalam upaya menurunkan risiko kejadian malnutrisi pada anak balita, terutama stunting. Setelah para aktivis dasa wisma memberikan pendampingan kepada ibu balita selama satu bulan ada peningkatan pengetahuan dan praktik dalam pemenuhan gizi anak balita dan kemampuan menentukan status gizi anak balita. Peran dasa wisma sangat penting untuk mendampingi ibu balita dalam pemantauan gizi balita, diharapkan semua ibu balita dan anggota dawis lainnya dapat berpartisipasi bukan hanya ibu ketua dawis yang aktif. Lebih aktifnya program dan kegiatan dari puskesmas kepada dasa wisma di bawah wilayah kerjanya untuk diberikan pembekalan terkait pemantauan status gizi. Lebih memanfaatkan adanya tetangga satu dasa wisma (peer educator) untuk saling mengingatkan dan membantu memberikan doro- ngan positif terkait pemantauan status gizi balita.

\section{UCAPAN TERIMA KASIH}

Penulis mengucapkan terima kasih kepada Direktorat Jenderal Kesehatan Masyarakat, Kementerian Kesehatan RI, khususnya Direktorat Gizi Masyarakat dan semua jajarannya. Fakultas Kesehatan Masyarakat Universitas Diponegoro, LPPM Universitas Diponegoro, Dinas Kesehatan Kota Semarang, Staff Puskesmas Tlogosari Wetan, aktivis dasa wisma Kecamatan Pedurungan Kelurahan Tlogosari Wetan, dan seluruh partisipan yang turun berkontribusi dalam proses penelitian.

\section{DAFTAR PUSTAKA}

1. Ikatan Dokter Anak Indonesia. Ilmu Kesehatan Anak. Jakarta: IDAI; 2010.

2. Kementerian Kesehatan Republik Indonesia. Pedoman pemantauan wilayah setempat Kesehatan Ibu dan Anak (PWS - KIA). Direktorat Jenderal Bina Kesehatan Masyarakat Direktorat Bina Kesehatan Ibu. Jakarta: Depkes RI; 2010.

3. Ilham. Kartu Menuju Sehat (KMS) Sarana untuk Pencapaian Derajat Kesehatan Anak. 2015.

4. Kementerian Kesehatan RI. Ayo ke Posyandu Setiap Bulan, Posyandu Menjaga Anak dan Ibu Tetap Sehat. Pusat Promosi Kesehatan. Jakarta: Depkes RI; 2015.

5. SediaoetamaA.D. Ilmu Gizi. Jakarta: Dian Rakyat; 2010.

6. Kementerian Kesehatan Republik Indonesia. Pedoman Pemantauan Wilayah Setempat Kesehatan Ibu dan Anak (PWS - KIA). Direktorat Jenderal Bina Kesehatan Masyarakat Direktorat Bina Kesehatan Ibu. Jakarta: Depkes RI; 2010.

7. Kementerian Kesehatan Republik Indonesia. Hasil Pemantauan Status Gizi (PSG) tahun 2016. Jakarta: Direktorat Bina Gizi Masyarakat, Dirjen Kesehatan Masyarakat; 2017.

8. Badan Penelitian dan Pengembangan Kesehatan. Kementerian Kesehatan Republik Indonesia. Jakarta: Riset Kesehatan Dasar (RISKESDAS); 2013.

9. Badan Penelitian dan Pengembangan Kesehatan. Kementerian Kesehatan Republik Indonesia. Jakarta: Riset Kesehatan Dasar (RISKES- 
DAS); 2013.

10. S. B. Ickes, C. Baguma, C. A. Brahe, J. A. Myhre, L. S. Adair, M. E. Bentley and A. S. Ammerman. Maternal Participation in a Nutrition Education Program in Uganda is Associated with Improved Infant and Young Child Feeding Practices and Feeding Knowledge: a Post-Program Comparison Study. BMC Nutrition. 2017;3(32): DOI 10.1186/s40795-0170140-8.

11. Bhandari N, Mazumder S, Bahl R, Martines J, Black RE, Bhan MK. An Educational Intervention to Promote Appropriate Complimentary Feeding Practices and Physical growth in Infants and Young Children in Rural Haryana. India J Nutr. 2004;139:2342-8.

12. Shi L, Zhang J, Wang Y, Caulfield LE, Guyer B. (2010). Effectiveness of an Educational Intervention on Complementary Feeding Practices and Growth in Rural China: a Cluster Randomized Controlled Trial. Public Health Nutr. 2010;13:556-65.

13. Bhandari N, Mazumder S, Bahl R, Martines J, Black RE, Bhan MK. An Educational Intervention to Promote Appropriate Complimentary Feeding Practices and Physical growth in Infants and Young Children in Rural Haryana. India J Nutr. 2004;139:2342-8.

14. Abebe, Z., Haki, G.D., Baye, K. Health Extension Workers' Knowledge and Knowledge-Sharing Effectiveness of Optimal Infant and Young Child Feeding are Associated with Mothers' Knowledge and Child Stunting in Rural Ethiopia. Food Nutr Bull. 2016; 37:353-
363.

15. Rahmariza Emilia, Ikeu Tanziha, Dadang Sukandar. Analisis Determinan Karakteristik Keluarga dan Pemenuhan Hak Kesehatan Anak serta Dampaknya terhadap Status Gizi. Jurnal MKMI. 2016;12(3):153-160.

16. Khomsan et al. Growth. Cognitive Development and Psychosocial Stimulation of Preschool Children in Poor Farmer and NonFarmer Householding. Bogor: Penelitian Neys van Hoogtraten Foundation. 2011.

17. Atmarita, Fallah TS. Analisis Situasi Gizi dan Kesehatan Masyarakat. di dalam: Soekirman, Seta AK, Pribadi N, Martianto D, Ariani M, Jus'at I, Hardinsyah, Dahrulsyah, Firdausy CM, editor. Widyakarya Nasional Pangan dan Gizi VIII: Ketahanan Pangan dan Gizi di Era Otonomi Daerah dan Globalisasi. Jakarta: LIPI. 2004.

18. Davidson Sarah Melati, Cesilia Meti Dwiriani, Ali Khomsan. Densitas Gizi dan Morbiditas serta Hubungannya dengan Status Gizi Anak Usia Prasekolah Pedesaan. Jurnal MKMI. 2018;14(3):251-259. DOI : http://dx. doi.org/10.30597/mkmi.v14i3.4551.

19. Adamu, Dube Jara, Mulunesh Alemayehu2 and Sahai Burrowes. Risk Factors Associated with Poor Health Outcomes for Children Under the Age of 5 with Moderate Acute Malnutrition in Rural Fagita Lekoma District, Awi Zone, Amhara, Ethiopia, 2016. BMC Nutrition. 2017;3(88). DOI 10.1186/s40795-0170208-5. 